\title{
Wilson disease presenting as a case of resistant rickets
}

\author{
Manjari Basu ${ }^{1}$ \\ Sri Lanka Journal of Child Health 2014; 43(2): 106-107
}

(Key words: Wilson disease; resistant rickets)

\section{Case report}

A 9 year old Muslim boy, born of a consanguineous marriage, presented with knock knees which were progressively increasing over the past year. He was active and playful. There was no history of convulsions, jaundice, drug intake or malabsorption.

On examination, his build and nutrition were average. There was genu valgum and widening of wrists. There was no alopecia or dental abnormality. There was no family history of similar abnormality.

X-ray of wrist was suggestive of rickets. Serum calcium was $9.5 \mathrm{mg} / \mathrm{dl}$ (normal range: 8.8-10.8 $\mathrm{mg} / \mathrm{dl}$ ), serum phosphate $2.5 \mathrm{mg} / \mathrm{dl}$ (normal range: 3.7-5.6 mg/dl) and serum alkaline phosphatase (ALP) 2311 U/L (normal range: 145-420 U/L). Parathyroid hormone (PTH) level was normal.

Patient received 2 doses of Vitamin D 600,000 units at 1 month interval in an outside hospital without any sign of recovery and he was diagnosed as resistant rickets of unknown cause. During follow-up visits, mother gave a history of the child's deteriorating school performance and emotional disturbances for 1 year. On examination, child had poor handwriting. Otherwise the neurological examination was normal. However, he had hepatomegaly with a liver span of $12 \mathrm{~cm}$. Further inquiry elicited a history of death of an uncle due to jaundice of unknown cause.

Further investigations were done. The haemoglobin ( $\mathrm{Hb})$ level was $8 \mathrm{~g} \%$, the reticulocyte count $4 \%$, aspartate aminotransferase (AST) $105 \mathrm{IU} / \mathrm{L}$, alanine aminotransferase (ALT) 86U/L, serum caeruloplasmin $12 \mathrm{mg} / \mathrm{dl}$ and urine copper 130 $\mu \mathrm{g} / 24 \mathrm{hrs}$. Urinary copper after penicillamine challenge was $930 \mu \mathrm{g} / 24 \mathrm{hrs}$. Both eyes showed Kayser-Fleischer (KF) rings on slit lamp examination.

${ }^{1}$ Assistant Professor, College of Medicine and JNM Hospital, WBUHS, Kalyani, India

(Received on 05 May 2013: Accepted after revision on 21 June 2013)

Urine examination showed phosphaturia and glycosuria. Thus we diagnosed the case as Wilson disease causing resistant rickets with osseo-muscular type genu valgum. We started treatment with Dpenicillamine, pyridoxine and zinc.

Parents continued the treatment for 1 month but after that discontinued it due to the high cost and came to follow-up long after 1year. By that time he had several neurological manifestations including chorea, tremor, and abnormal gait.

\section{Discussion}

Wilson disease is a rare autosomal recessive disorder characterized by a toxic accumulation of copper in liver, brain, cornea, skeletal system and other tissues ${ }^{1}$. The abnormal gene of Wilson disease is located on the long arm of chromosome 13 at q 14$\mathrm{q} 21^{1}$.

Clinical presentation of Wilson disease in India does not always follow the pattern usually seen in the western world ${ }^{1}$. Wadia et al first drew attention in this regard and observed that generalized osteoporosis, rickets or even renal rickets could be striking manifestation in at least 8 of 23 patients ${ }^{2}$. Rickets and osteoporosis as presenting feature are also reported by a few other Indian authors ${ }^{3,4}$.

In Wilson disease there is hypophosphataemic type resistant rickets as there is normal calcium, low phosphate, elevated ALP and normal PTH. The cause of hypophosphatemia is proximal renal tubular acidosis (RTA) as there is phosphaturia and glycosuria. In Wilson disease copper causes damage to renal tubular cells. That causes proximal RTA. Proximal RTA causes phosphaturia leading to hypophosphatemia. It leads to rickets.

\section{References}

1. Pandit A, Bavdekar A, Bhave S. Wilson disease. Indian Journal of Pediatrics 2002; 69(9):785-91. http://dx.doi.org/10.1007/BF02723693 
2. Wadia NH, Dastur DK. Wilson's disease in four Indian families. Neurology India 1963; 11:1-6.

3. Goyal JP, Kumar N, Rao SS, Shah VB. Wilson's disease presenting as resistant rickets. Gastroenterology Research 2011; 4(1):34-5.
4. Kabra SK, Bagga A, Malkani I. wilson's disease presenting with refractory rickets. Indian Pediatrics 1990; 27(4):395-7. 